\title{
RESISTENCE OF EUPHORBIA HETEROPHYLLA L. TO ALS-INHIBITING HERBICIDES IN SOYBEAN
}

\author{
Gerson Augusto Gelmini1*; Ricardo Victória Filho²; Maria do Carmo de Salvo Soares Novo; \\ Márcio Luiz Adoryan ${ }^{2}$ \\ ${ }^{1}$ Coordenadoria de Defesa Agropecuária - Av. Brasil, 2340 - 13073-001 - Campinas - SP - Brasil. \\ ${ }^{2}$ USP/ESALQ - Depto. de Produção Vegetal, C.P. 09 - 13418-900 - Piracicaba, SP - Brasil. \\ ${ }^{3}$ IAC - Centro de Ecofisiologia e Biofísica, C.P. 28 - 13001-970 - Campinas - SP - Brasil. \\ *Corresponding author <gelmini@cda.sp.gov.br>
}

\begin{abstract}
Herbicides are widely used in soybean for weed control, and the selection pressure attributed to the repeated use of herbicides with similar modes of action on the same site has caused selection for resistant biotypes within and among previously susceptible species, such as Euphorbia heterophylla L., in relation to ALS enzyme inhibitors, in the states of Paraná, Rio Grande do Sul, and São Paulo, Brazil. Seeds of E. heterophylla were collected to examine possible new cases of resistant populations and to test alternative herbicide treatments to manage these populations, in the Caarapó region, State of Mato Grosso do Sul, Brazil, in areas where plants of this species have survived continuous herbicide applications. The experiment was carried out under greenhouse conditions, where biotypes with a history of suspected resistance were compared with a known susceptible biotype. Several post-emergence herbicides were sprayed at zero, one, two, four, and eight times the recommended field application rates. Twenty days after application, plants were harvested, and control percentage and fresh weight were determined to establish dose-response curves, in the aim to obtain the resistance factor using $\mathrm{CD}_{50}$ and $\mathrm{RD}_{50}$ data. The chlorimuron-ethyl resistance factor values for the control percentage and fresh weight parameters were higher than 16.5 and 16.9, respectively, while imazethapyr showed resistance factors higher than 25.0 and 23.5, respectively. The resistant biotype showed different resistance levels to chlorimuron-ethyl and imazethapyr, showing cross-resistance to the sulfonylurea and imidazolinone groups. Nevertheless, this biotype was effectively controlled by fomesafen $\left(250 \mathrm{~g} \mathrm{ha}^{-1}\right)$, lactofen $\left(120 \mathrm{~g} \mathrm{ha}^{-1}\right)$, flumiclorac-pentyl $\left(40 \mathrm{~g} \mathrm{ha}^{-1}\right)$, glufosinate-ammonium $\left(150 \mathrm{~g} \mathrm{ha}^{-1}\right)$, and glyphosate $\left(360 \mathrm{~g} \mathrm{ha}^{-1}\right)$. Key words: milkweed, cross-resistance, imidazolinone, sulfonylurea
\end{abstract}

\section{RESISTENCIA DE EUPHORBIA HETEROPHYLLA L. AOS HERBICIDAS INIBIDORES DA ALS NA CULTURA DA SOJA}

RESUMO: Os herbicidas constituem a principal medida de controle de plantas daninhas na cultura da soja, mas através da pressão de seleção, o uso contínuo e prolongado de produtos com o mesmo mecanismo de ação pode provocar a manifestação de biótipos resistentes, como ocorreu com Euphorbia heterophylla L. aos inibidores da ALS nos Estados do Paraná, Rio Grande do Sul e São Paulo. Para verificar possíveis novos casos, bem como alternativas para prevenção e manejo, foram coletadas sementes dessa espécie daninha na região de Caarapó (MS), em plantas que sobreviveram a tratamentos onde esses herbicidas foram sistematicamente aplicados nos últimos anos. Em casa-de-vegetação, comparou-se o efeito dos principais herbicidas usados em pós-emergência na cultura da soja sobre o biótipo com histórico de resistência e sobre um suscetível sendo instalado, um experimento em blocos ao acaso para cada produto $(n=4)$. Os herbicidas foram aplicados quando as plantas apresentavam de duas a quatro folhas verdadeiras nas doses zero, uma, duas, quatro e oito vezes a recomendação do fabricante. Aos vinte dias após a aplicação, foram avaliados parâmetros relativos ao controle e produção de fitomassa epígea com base nos valores de $\mathrm{DC}_{50} \mathrm{e} \mathrm{GR}_{50}$. Foi determinado também o fator de resistência (FR), que representa o número de vezes em que a dose necessária para proporcionar $50 \%$ de controle ou de redução na produção de fitomassa epígea do biótipo suscetível deve ser aumentada, para que possa ocorrer o mesmo efeito sobre o resistente. O biótipo resistente apresentou diferentes níveis de resistência aos herbicidas chlorimuronethyl e imazethapyr, demonstrando ser portador de resistência cruzada aos inibidores da ALS dos grupos das sulfoniluréias e imidazolinonas. O fator de resistência para chlorimuron-ethyl foi superior a 16,5 para a porcentagem de controle e a 16,9 para a produção de fitomassa epígea, enquanto que para imazethapyr, o fator de resistência foi superior a 25,0 e a 23,5, respectivamente. O biótipo resistente foi eficientemente controlado nos tratamentos com os herbicidas fomesafen $\left(250 \mathrm{~g} \mathrm{ha}^{-1}\right)$, lactofen $\left(120 \mathrm{~g} \mathrm{ha}^{-1}\right)$, flumiclorac-pentil $\left(40 \mathrm{~g} \mathrm{ha}^{-1}\right)$, glufosinato de amônio (150 $\left.\mathrm{g} \mathrm{ha}^{-1}\right)$ e glyphosate $\left(360 \mathrm{~g} \mathrm{ha}^{-1}\right)$.

Palavras-chave: leiteira, resistência cruzada, imidazolinona, sulfoniluréia

Sci. Agric. (Piracicaba, Braz.), v.62, n.5, p.452-457, Sept./Oct. 2005 


\section{INTRODUCTION}

Among the management techniques adopted in soybean crops, an appropriate and convenient weed management to minimize the effects of undesirable interferences of weeds is highly important, not only for the production of higher yields per area unit, but also to reduce expenses with inputs and production costs in general (Pitelli, 1985; Burnside, 1992). However, the constant use of a herbicide or herbicides with the same action mechanism may exert a high selection pressure, reducing the susceptible population and consequently resulting in manifestations of resistant biotypes, which probably already existed in the population, but at very low frequencies (Holt \& LeBaron, 1990; Ponchio, 1997; Mattielo et al., 1999).

In Brazil, herbicide resistance cases have been reported for some weeds commonly found in soybean (Embrapa, 1999). Resistance of Euphorbia heterophylla L., one of the most important soybean crop weeds to herbicides that inhibit the enzyme acetolactate synthaseALS, has been reported for producing areas in the states of Paraná, Rio Grande do Sul, and São Paulo (Gazziero et al., 1998; Vidal \& Merotto Jr.; 1999; Vargas et al., 1999a; 1999b). The main reason for its manifestation is related to the presence of an ALS form that is insensitive to the action of these herbicides (Vidal, 1997). However, biotypes have proved susceptible to herbicides with different action mechanisms (Gazziero et al., 1998; Vidal \& Merotto Jr., 1999; Vargas et al., 1999a; 1999b).

Considering that these biotypes may present resistance to other herbicides that act on the same enzyme, it is important to study the existence of multiple resistance to different products to weeds can be effectively controlled. Therefore, the objectives of this work were to determine resistance to herbicides of the E. heterophylla biotype from the Caarapó (MS) region; establishing the magnitude of doses required to cause the same effect on susceptible and resistant plants; and evaluating the presence of multiple resistance to herbicides with other mechanisms of action that could be applied post-emergence in soybean.

\section{MATERIAL AND METHODS}

The experiment was carried out in Cosmópolis (SP), with E. heterophylla seeds collected at the end of the 1996/97 cropping season, from approximately one hundred plants that survived systematics applications of several ALS-inhibiting herbicides, in a soybean-producing area in the Caarapó (MS) region $\left(54^{\circ} 56^{\prime} \mathrm{W}, 22^{\circ} 41^{\prime} \mathrm{S}\right.$; altitude $470 \mathrm{~m}$ ). For comparison purpose, seeds from a susceptible biotype collected at a neighboring area that showed resistance history were used.
Seeds were air-dried, cleaned, packed and stored in refrigerated chamber at $9^{\circ} \mathrm{C}$ and $25 \%$ moisture and later on sown (11/29/98) on 1.3-L, perforated plastic pots containing a substrate made out of three parts dirt to one part humus, ten seeds per pot. Substrate's chemical and physical analyses showed: $\mathrm{P}=185 \mathrm{mg} \mathrm{dm}^{-3}$; organic matter $=$ $18.8 \mathrm{~g} \mathrm{dm}^{-3} ; \mathrm{CEC}=128 \mathrm{mmol}_{\mathrm{c}} \mathrm{dm}^{-3} ; \mathrm{V}=79.8 \%$; sand $=$ $118 \mathrm{~g} \mathrm{~kg}^{-1}$, and clay $=102 \mathrm{~g} \mathrm{~kg}^{-1}$. Thinning to four seedling was done after germination and pots were irrigated as required.

The experiment was arranged in randomized blocks, factorial scheme $2 \times 5$, comparing combinations between resistant and susceptible biotypes and five herbicide doses $(n=4)$. Effects of the main herbicides used in post-emergence in soybean on the supposedly-resistant and susceptible biotypes were compared in a greenhouse trial, one assay per product. The seven herbicides, were applied post-emergence as follows: chlorimuron-ethyl (2-(()((4chloro-6- methoxypyrimidin-2-yl) amino) carbonyl) amino) sulfonyl) benzoate) at $0,15,30,60$, and $120 \mathrm{~g} \mathrm{ha}^{-1}$; imazethapyr (2-[4.5-dihydro-4-methyl-4-(1-methylethyl)-5oxo-1H-imidazol-2-yl]-5-ethyl-3- pyridinecarboxylic acid) at $0,100,200,400$, and $800 \mathrm{~g} \mathrm{ha}^{-1}$; fomesafen (5-[2-chloro4-(trifluoromethyl)phenoxy]-N-(methylsulfonyl)-2nitrobenzamide) at $0,250,500,1,000$, and 2,000 $\mathrm{g} \mathrm{ha}^{-1}$; lactofen (2-ethoxy-1-methyl-2-oxoethyl 5-[2-chloro-4(trifluoromethyl)phenoxy]-2-nitrobenzoate) at 0, 120, 240, 480, and $960 \mathrm{~g} \mathrm{ha}^{-1}$; flumiclorac-pentyl (pentyl-[2-chloro5-(cyclohex-1-ene-1,2-dicarboximido)-4-fluoro-phenoxy] acetate) at $0,40,80,160$, and $320 \mathrm{~g} \mathrm{ha}^{-1}$; glufosinate-ammonium (ammonium-DL-homoalanine-4-yl-(methyl) phosphinic acid) at 0, 150, 300,600, and 1,200 $\mathrm{g} \mathrm{ha}^{-1}$; and glyphosate (N-(phosphonomethyl) glycine) at $0,180,360$, 720 , and $1,440 \mathrm{~g} \mathrm{ha}^{-1}$. The chlorimuron-ethyl, flumicloracpentyl, fomesafen, and glufosinate-ammonium spray mixes were added of mineral oil at 0.05 and $0.2 \%(\mathrm{v} / \mathrm{v})$, and oxyethylated nonylphenol and isopropyl alcohol adjuvants at $0.2 \%(\mathrm{v} / \mathrm{v})$, respectively. The herbicides were applied on $12 / 12 / 98$ when plantlets showed from two to four true leaves, using a (compressed air) pressurized precision sprayer, equipped with a boom containing six flat-fan, continuous-deposition tips (XR110.015), spaced at $0.40 \mathrm{~m}$ and maintained at $0.50 \mathrm{~m}$ from the soil surface. A $250 \mathrm{kPa}$ work pressure allowed an intake corresponding to $200 \mathrm{~L} \mathrm{ha}^{-1}$ of mix.

The evaluation was done twenty days after application using a percentage rating scale where the absence of injury corresponded to zero, and plant death corresponded to 100. During the same season, plants in all treatments were cut even with the ground and weighed to obtain fresh epigeal phytomass. For statistical purpose, the Hartley test $\left(\mathrm{F}_{\text {max }}\right)$ was used to verify whether data were homoscedastic. Regular heteroscedasticity of the percentage data was observed so they were transformed to arc sine $(x / 100)^{1 / 2}$. 
Data were submitted to ANOVA ( $F$ test) to identify differences between biotypes, product doses, and interactions between doses and biotypes. Because the interaction was highly significant, the treatment means were compared with the different doses of each product within each biotype, as well as the means of each biotype within product doses. The effect of doses of each herbicide within each biotype was characterized by a fitted equation that best represented the behavior for the variable. Only equations bearing coefficients of determination $\left(\mathrm{R}^{2}\right)$ equal to or higher than 0.96, and had biological significance were considered; only partitioning of analysis where the F test was significant were discussed.

To compare responses, doses that provided $50 \%$ control $\left(\mathrm{CD}_{50}\right)$ or percentage of fresh epigeal phytomass yield in relation to the control $\left(\mathrm{RD}_{50}\right)$, based on the fitted equations were calculated. Considering these values, the resistance factor $(\mathrm{RF})$ was determined, representing the number of times by which the dose required to provide a $50 \%$ control or reduction of fresh epigeal phytomass yield in the susceptible biotype should be increased for the same effect to be achieved in the resistant biotype.

\section{RESULTS AND DISCUSSION}

Only chlorimuron-ethyl and imazethapyr did not control the biotype with a resistance history (Table 1). The control index for the resistant biotype being studied varied from zero to $7.5 \%$ for chlorimuron-ethyl, and from 2.5 to $15.0 \%$ for imazethapyr; regarding the susceptible

CHLORIMURON-ETHYL
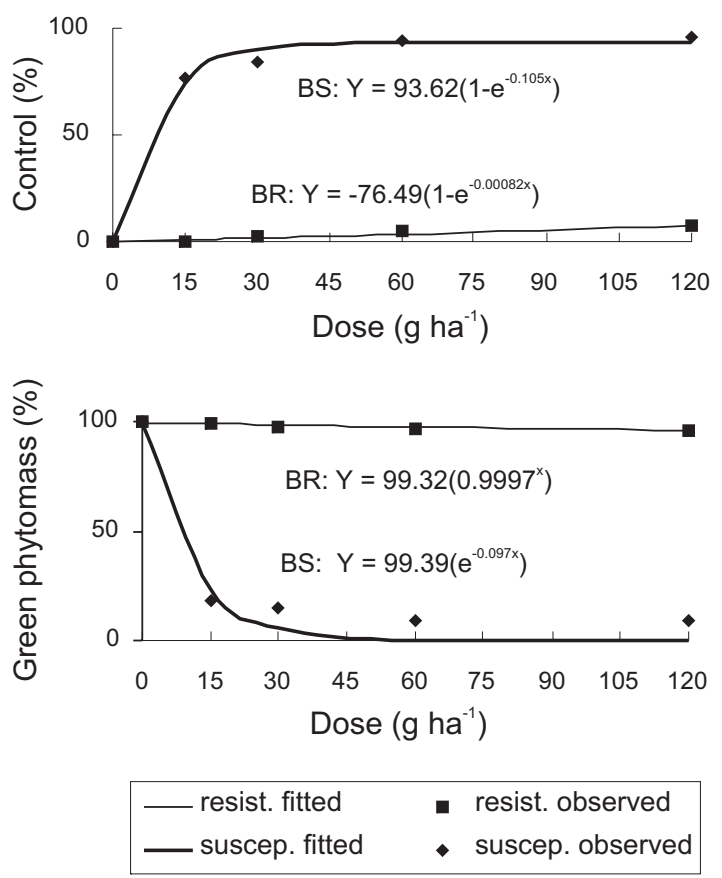

biotype, success control lied between 76.0 and $99.0 \%$ for chlorimuron-ethyl, and between 85.0 and $98.0 \%$ for imazethapyr (Table 1). The extension of damages observed in the susceptible biotype, both for chlorimuronethyl and imazethapyr, was visibly different from that observed in the resistant. Yellow epigeal part and later death of plants were observed in the susceptible biotype treated with chlorimuron-ethyl; plants of the resistant biotype remained always green. Growth stopped in the susceptible biotype treated with imazethapyr few days after application. Typical symptoms of this product such as apical meristem necrosis, degeneration, and death of plants (Rodrigues \& Almeida, 1998) were observed later on.

With regard to fresh epigeal phytomass, it was observed for both herbicides that the yield percentages of the biotype under study were equal to the control, while in the susceptible they varied from 8.0 to $19.0 \%$ and from 4.0 to $11.0 \%$, respectively (Table 1). According to Mallory-Smith et al. (1990), when no expressive reduction in fresh matter weight occurs due to the action of sulfonylureas, even at high rates, it is suggested that a change in the site of activity of these products has occurred, this being the most widely accepted reason for the observed resistance.

In relation to the control percentage in the resistant biotype, the equation fitted for chlorimuron-ethyl followed Harris model, while a linear equation was fitted for imazethapyr; regarding the susceptible biotype, Harris model was proved more appropriate (Figure 1). The fresh epigeal phytomass yield data in the resistant and
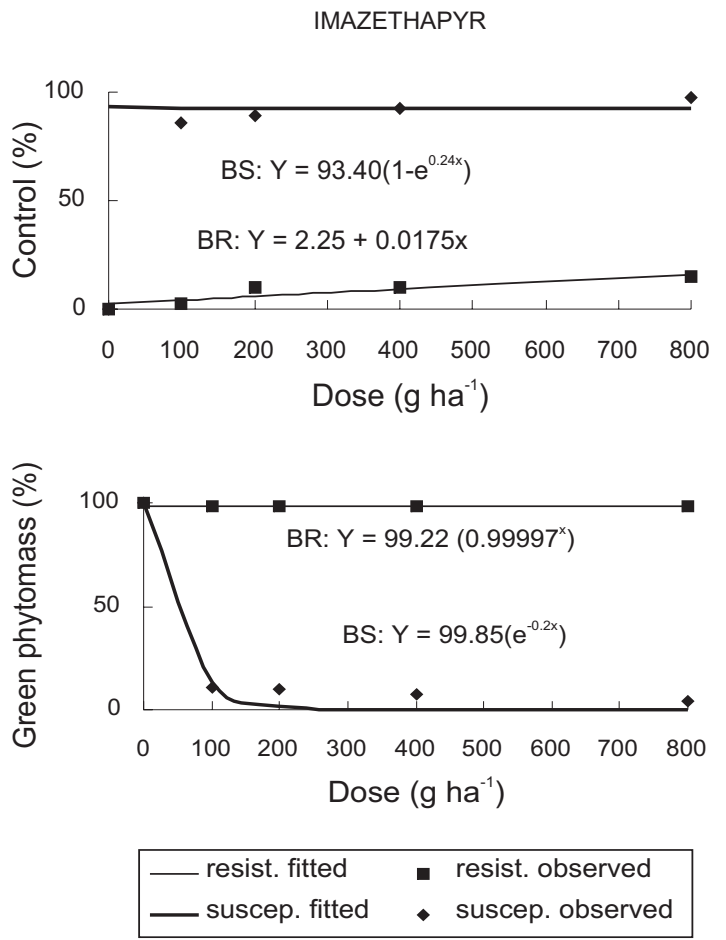

Figure 1 - Dose-response curves for the herbicides chlorimuron-ethyl and imazethapyr in the resistant (BR) and susceptible (BS) Euphorbia heterophylla L. biotypes. 
Table 1 - Comparison between a resistant (BR) and a susceptible (BS) Euphorbia heterophylla L. biotype in each dose of different herbicides, applied post-emergence, with regard to control percentage and fresh epigeal phytomass yield at 20 days after application.

\begin{tabular}{|c|c|c|c|c|c|}
\hline \multirow{2}{*}{ Treatment } & \multirow{2}{*}{ Dose g.a.i. ${ }^{3}$} & \multicolumn{2}{|c|}{ Control $^{1}$} & \multicolumn{2}{|c|}{ Fresh epigeal phytomass ${ }^{2}$} \\
\hline & & BR & BS & BR & BS \\
\hline \multicolumn{6}{|c|}{$\mathrm{g} \mathrm{ha}^{-1}$} \\
\hline & 0 & $0.00 \mathrm{a}$ & $0.00 \mathrm{a}$ & $100.00 \mathrm{a}$ & $100.00 \mathrm{a}$ \\
\hline & 15 & $0.00 \mathrm{~b}$ & $76.25 \mathrm{a}$ & $98.90 \mathrm{a}$ & $18.22 \mathrm{~b}$ \\
\hline \multirow[t]{3}{*}{ chlorimuron-ethyl } & 30 & $2.50 \mathrm{~b}$ & $84.50 \mathrm{a}$ & $97.24 \mathrm{a}$ & $15.04 \mathrm{~b}$ \\
\hline & 60 & $5.00 \mathrm{~b}$ & $94.50 \mathrm{a}$ & $96.68 \mathrm{a}$ & $9.15 \mathrm{~b}$ \\
\hline & 120 & $7.50 \mathrm{~b}$ & $98.75 \mathrm{a}$ & $96.19 \mathrm{a}$ & $8.77 \mathrm{~b}$ \\
\hline \multirow[t]{3}{*}{$\mathrm{CV} \%$} & & 3.5 & & \multicolumn{2}{|c|}{2.0} \\
\hline & 0 & $0.00 \mathrm{a}$ & $0.00 \mathrm{a}$ & $100.00 \mathrm{a}$ & $100.00 \mathrm{a}$ \\
\hline & 100 & $2.50 \mathrm{~b}$ & $85.75 \mathrm{a}$ & $98.55 \mathrm{a}$ & $10.90 \mathrm{~b}$ \\
\hline \multirow[t]{3}{*}{ imazethapyr } & 200 & $10.00 \mathrm{~b}$ & $88.75 \mathrm{a}$ & $98.53 \mathrm{a}$ & $9.77 \mathrm{~b}$ \\
\hline & 400 & $10.00 \mathrm{~b}$ & $92.50 \mathrm{a}$ & $98.33 \mathrm{a}$ & $7.77 \mathrm{~b}$ \\
\hline & 800 & $15.00 \mathrm{~b}$ & $97.50 \mathrm{a}$ & $98.22 \mathrm{a}$ & $4.40 \mathrm{~b}$ \\
\hline \multirow[t]{3}{*}{$\mathrm{CV} \%$} & & 3.3 & & \multicolumn{2}{|c|}{2.4} \\
\hline & 0 & $0.00 \mathrm{a}$ & $0.00 \mathrm{a}$ & $100.00 \mathrm{a}$ & $100.00 \mathrm{a}$ \\
\hline & 250 & $83.75 \mathrm{~b}$ & $87.25 \mathrm{a}$ & $14.54 \mathrm{a}$ & $14.77 \mathrm{a}$ \\
\hline \multirow[t]{3}{*}{ fomesafen } & 500 & $86.50 \mathrm{~b}$ & $92.75 \mathrm{a}$ & $13.27 \mathrm{a}$ & $13.11 \mathrm{a}$ \\
\hline & 1,000 & $90.25 \mathrm{a}$ & $96.50 \mathrm{a}$ & $10.76 \mathrm{a}$ & $8.92 \mathrm{a}$ \\
\hline & 2,000 & $99.50 \mathrm{a}$ & $100.00 \mathrm{a}$ & $1.76 \mathrm{a}$ & $1.73 \mathrm{a}$ \\
\hline \multirow[t]{3}{*}{$\mathrm{CV} \%$} & & 3.1 & & \multicolumn{2}{|c|}{2.2} \\
\hline & 0 & $0.00 \mathrm{a}$ & $0.00 \mathrm{a}$ & $100.00 \mathrm{a}$ & $100.00 \mathrm{a}$ \\
\hline & 40 & $88.75 \mathrm{~b}$ & $90.75 \mathrm{a}$ & $11.79 \mathrm{a}$ & $11.22 \mathrm{a}$ \\
\hline \multirow[t]{3}{*}{ lactofen } & 80 & $92.50 \mathrm{a}$ & $93.25 \mathrm{a}$ & $9.30 \mathrm{a}$ & $9.78 \mathrm{a}$ \\
\hline & 160 & $99.00 \mathrm{a}$ & $96.50 \mathrm{a}$ & $2.44 \mathrm{a}$ & $2.49 \mathrm{a}$ \\
\hline & 320 & $100.00 \mathrm{a}$ & $99.00 \mathrm{a}$ & $2.36 \mathrm{a}$ & $2.13 \mathrm{a}$ \\
\hline \multirow[t]{3}{*}{$\mathrm{CV} \%$} & & 3.3 & & \multicolumn{2}{|c|}{2.1} \\
\hline & 0 & $0.00 \mathrm{a}$ & $0.00 \mathrm{a}$ & $100.00 \mathrm{a}$ & $100.00 \mathrm{a}$ \\
\hline & 40 & $88.75 \mathrm{~b}$ & $90.75 \mathrm{a}$ & $11.79 \mathrm{a}$ & $11.22 \mathrm{a}$ \\
\hline \multirow[t]{3}{*}{ flumiclorac-pentyl } & 80 & $92.50 \mathrm{a}$ & $93.25 \mathrm{a}$ & $9.30 \mathrm{a}$ & $9.78 \mathrm{a}$ \\
\hline & 160 & $99.00 \mathrm{a}$ & $96.50 \mathrm{a}$ & $2.44 \mathrm{a}$ & $2.49 \mathrm{a}$ \\
\hline & 320 & $100.00 \mathrm{a}$ & $99.00 \mathrm{a}$ & $2.36 \mathrm{a}$ & $2.13 \mathrm{a}$ \\
\hline \multirow[t]{3}{*}{$\mathrm{CV} \%$} & & 3.3 & & \multicolumn{2}{|c|}{2.1} \\
\hline & 0 & $0.00 \mathrm{a}$ & $0.00 \mathrm{a}$ & $100.00 \mathrm{a}$ & $100.00 \mathrm{a}$ \\
\hline & 150 & $87.75 \mathrm{a}$ & $85.75 \mathrm{a}$ & $12.69 \mathrm{~b}$ & $14.67 \mathrm{a}$ \\
\hline \multirow[t]{3}{*}{ glufosinate- ammonium } & 300 & $93.75 \mathrm{a}$ & $92.50 \mathrm{a}$ & $3.67 \mathrm{a}$ & $3.59 \mathrm{a}$ \\
\hline & 600 & $99.50 \mathrm{a}$ & $97.00 \mathrm{a}$ & $2.40 \mathrm{a}$ & $2.07 \mathrm{a}$ \\
\hline & 1,200 & $100.00 \mathrm{a}$ & $97.50 \mathrm{a}$ & $2.00 \mathrm{a}$ & $1.74 \mathrm{a}$ \\
\hline \multirow[t]{3}{*}{$\mathrm{CV} \%$} & & 2.8 & & \multicolumn{2}{|c|}{2.3} \\
\hline & 0 & $0.00 \mathrm{a}$ & $0.00 \mathrm{a}$ & $100.00 \mathrm{a}$ & $100.00 \mathrm{a}$ \\
\hline & 180 & $65.00 \mathrm{a}$ & $61.25 \mathrm{a}$ & $56.63 \mathrm{a}$ & $57.81 \mathrm{a}$ \\
\hline \multirow[t]{3}{*}{ glyphosate } & 360 & $83.75 \mathrm{a}$ & $86.25 \mathrm{a}$ & $15.58 \mathrm{a}$ & $16.61 \mathrm{a}$ \\
\hline & 720 & $95.75 \mathrm{a}$ & $98.75 \mathrm{a}$ & $8.99 \mathrm{a}$ & $9.80 \mathrm{a}$ \\
\hline & 1,440 & $100.00 \mathrm{a}$ & $100.00 \mathrm{a}$ & $2.44 \mathrm{a}$ & $2.42 \mathrm{a}$ \\
\hline $\mathrm{CV} \%$ & & 3.3 & & & \\
\hline
\end{tabular}

${ }^{1}$ Means followed by the same letter in the row, do not differ by the $\mathrm{F}$ test $(\alpha=0.05)$.

${ }^{2}$ Fresh epigeal phytomass yield percentage in relation to the control.

${ }^{3}$ g.a.i. - grams of active ingredient. 
susceptible biotypes, both for chlorimuron-ethyl and imazethapyr in relation to the control, followed an exponential-fitting curve. On the other hand, the $\mathrm{CD}_{50}$ and $\mathrm{RD}_{50}$ values calculated by the equations showed that even when doses eight times as high as the recommended chlorimuron-ethyl or imazethapyr rates were applied, the resistant biotype was not controlled nor was there a reduction in fresh epigeal phytomass yield. However, the recommended rate was effective against the susceptible biotype (Table 2). According to Cortez (2000), when establishing dose-response curves as a function of herbicide rates and response variables, the dependent variable behavior may not follow a sigmoidal-shaped curve as occurred in this experiment. Models such as linear and quadratic regression, hyperbolic, and exponential equations could be used. Cortez (2000) reported that it is also possible to use non-linear functions.

The resistance factor for chlorimuron-ethyl was higher than 16.5 for control percentage and 16.9 for fresh epigeal phytomass yield, while for imazethapyr the resistance factor was higher than 25.0 and 23.5, respectively (Table 3). This fact provides clear evidence of manifestation of cross-resistance to the ALS inhibitors represented by these herbicides in the groups of sulfonylureas and imidazolinones, as preconized by Powles \& Howat (1990) and Vargas et al. (1999a; 1999b), and consonant with results previously reported by Gazziero et al. (1998),
Vargas et al. (1999a), and Vidal \& Merotto Jr. (1999). Since resistance was observed at doses above the recommended rates, results are in agreement with Gressel \& Segel (1978), Holt \& LeBaron (1990), and Warwick (1991), and the hypothesis that it was induced by the continued and prolonged use of herbicides with the same mechanism of action, as stated by Betts et al. (1992), is admitted. The manifestation of resistance could be related to the presence of genotypes that would survive in the original community at very low levels, as considered by Guttieri et al. (1992) and Mattielo et al. (1999).

The total post-emergence herbicides ordinarily used in soybean, like fomesafen $\left(250 \mathrm{~g} \mathrm{ha}^{-1}\right)$, lactofen $\left(120 \mathrm{~g} \mathrm{ha}^{-1}\right)$, and flumiclorac-pentyl $\left(40 \mathrm{~g} \mathrm{ha}^{-1}\right)$, in addition to glufosinate-ammonium $\left(150 \mathrm{~g} \mathrm{ha}^{-1}\right)$ and glyphosate $\left(360 \mathrm{~g} \mathrm{ha}^{-1}\right)$, with their corresponding adjuvants added to the spray mix, provided effective control (Table 1), becoming important options not only to minimize the effects of undesirable selection, but also for management of the resistant population. Vidal et al. (1997) reported an effective control of biotypes resistant to ALS-inhibiting herbicides provided by fomesafen, lactofen, and glyphosate, and Gazziero et al. (1998) identified lactofen and sulfentrazone as viable alternatives. Vargas et al. (1999a; 1999b) observed effective control of a resistant biotype when submitted to treatment with fomesafen, lactofen, glyphosate, and glufosinate-ammonium applied

Table 2 - Fitted equations for the control and fresh epigeal phytomass yield of chlorimuron-ethyl and imazethapyr, in the resistant (BR) and susceptible (BS) Euphorbia heterophylla L. biotypes.

\begin{tabular}{|c|c|c|}
\hline \multirow{2}{*}{ Biotype } & Control & Fresh epigeal phytomass \\
\hline & \multicolumn{2}{|c|}{ - } \\
\hline \multicolumn{3}{|c|}{ Chlorimuron-ethyl } \\
\hline BR & $y=76.49\left(1-e^{-0.00082 x}\right)$ & $y=99.32\left(0.9997^{x}\right)$ \\
\hline BS & $\mathrm{y}=93.62\left(1-\mathrm{e}^{-0.105 x}\right)$ & $\mathrm{y}=99.39 \quad\left(\mathrm{e}^{-0.097 \mathrm{x}}\right)$ \\
\hline \multicolumn{3}{|c|}{ Imazethapyr } \\
\hline $\mathrm{BR}$ & $y=2.25+0.0175 x$ & $y=99.22\left(0.99997^{x}\right)$ \\
\hline BS & $y=93.40\left(1-e^{0.24 x}\right)$ & $\mathrm{y}=99.85\left(\mathrm{e}^{-0.2 x}\right)$ \\
\hline
\end{tabular}

Table $3-\mathrm{CD}_{50}, \mathrm{RD}_{50}$, and resistance factor (RF) values for the herbicides chlorimuron-ethyl and imazethapyr relative to control and fresh epigeal phytomass yield percentages in the resistant (BR) and susceptible (BS) Euphorbia heterophylla $\mathrm{L}$. biotypes.

\begin{tabular}{|c|c|c|c|c|c|}
\hline \multirow{2}{*}{ Biotype } & \multicolumn{2}{|c|}{ Control } & \multirow{2}{*}{ Biotype } & \multicolumn{2}{|c|}{ Fresh epigeal phytomass } \\
\hline & $\mathrm{CD}_{50}$ & $\mathrm{RF}$ & & $\mathrm{RD}_{50}$ & $\mathrm{RF}$ \\
\hline \multicolumn{4}{|c|}{ 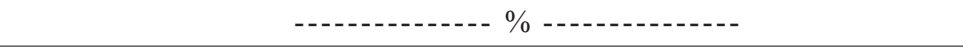 } & 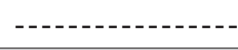 & --- \\
\hline \multicolumn{6}{|c|}{ Chlorimuron-ethyl } \\
\hline $\mathrm{BR}$ & $>120$ & $>16.51$ & BR & $>120$ & $>16.95$ \\
\hline BS & 7.27 & & BS & 7.08 & \\
\hline \multicolumn{6}{|c|}{ Imazethapyr } \\
\hline $\mathrm{BR}$ & $>800$ & $>25.28$ & BR & $>800$ & $>23.50$ \\
\hline BS & 31.65 & & BS & 34.04 & \\
\hline
\end{tabular}

Sci. Agric. (Piracicaba, Braz.), v.62, n.5, p.452-457, Sept./Oct. 2005 
at the recommended doses, while Buzatti (1999) and Silva (1999) indicated the use of alternatives such as fomesafen and lactofen in this situation.

\section{REFERENCES}

BETTS, K.J.; EHLKE, N.J.; WYSE, D.L.; GRONWALD, J.W.; SOMERS, D.A. Mechanism of inheritance of diclofop resistance in Italian ryegrass (Lolium multiflorum). Weed Science, v.40, p.184-189, 1992.

BURNSIDE, O.C. Rationale for developing herbicide-resistant crops. Weed Technology, v.6, p.621-625, 1992.

BUZATTI, W.J.S. Casos de resistência de plantas daninhas de leiteiro (Euphorbia heterophylla) e papuã (Brachiaria plantaginea) na região dos Campos Gerais do Paraná. In: CURSO DE MANEJO DA RESISTENCIA DE PLANTAS DANINHAS AOS HERBICIDAS, 2., Ponta Grossa, 1999. Anais. Ponta Grossa: AECG, 1999. p.132-140.

CORTEZ, M.G. Resistência de biotipos de Brachiaria plantaginea (Link.) Hitchc. a herbicidas inibidores da acetil coenzima a carboxilase. Piracicaba: USP/ESALQ, 2000. 214p. (Tese - Doutorado)

EMPRESA BRASILEIRA DE PESQUISA AGROPECUÁRIA. Recomendações técnicas para a cultura da soja na região central do Brasil 1999/2000. Londrina: Embrapa Soja, 1999. 226p.

GAZZIERO, D.L.P.; BRIGHENTI, A.M.; MACIEL, C.G.; CHRISTOFFOLETI, P.J.; ADEGAS, F.S.; VOLL, E. Resistência de amendoim-bravo aos herbicidas inibidores da enzima ALS. Planta Daninha, v.16, p.117-125, 1998.

GRESSEL, J.; SEGEL, L.A. The pancity of genetic adaptative resistance of plants to herbicides: possible biological reasons and implications. Journal of Theorical Biology, v.75, p.349-371, 1978.

GUTIERI, M.J.; EBERLEIN, C.V.; MALLORY-SMITH, C.A.; THILL, D.C., HOFFMAN, D.L. DNA sequence variation in domain A of the acetolactate synthase genes of herbicide-resistant and susceptible weed biotypes. Weed Science, v.40, p.670-676, 1992.

HOLT, J.S.; LeBARON, H.M. Significance and distribution of herbicide resistance. Weed Technology, v.4, p.141-149, 1990.

MALLORY-SMITH, C.A., THILL, D.C.; DIAL, M.J.; ZEMETRA, R.S. Inheritance of sulfonylurea herbicide resistance in Lactuca spp. Weed Technology, v.4, p.787-790, 1990.
MATTIELO, R.R.; RONZELI JR; P.; PURISSIMO, C. Mecanismos de resistência; fatores biológicos, agronômicos e genéticos. In: CURSO DE MANEJO DA RESISTENCIA DE PLANTAS DANINHAS AOS HERBICIDAS, 2., Ponta Grossa, 1999. Anais. Ponta Grossa: AECG, 1999. p.27-40.

PITELLI, R.A. Interferência de plantas daninhas em culturas agrícolas. Informe Agropecuário, v.2, p. 16-27, 1985.

PONCHIO, J.A.R. Resistência de Bidens pilosa L. aos herbicidas inibidores da enzima ecetolactato sintase. Piracicaba: ESALQ/USP, 1997. 138p. (Tese - Doutorado).

POWLES, S.B.; HOWAT, P.D. Herbicide-resistant weeds in Australia. Weed Technology, v.4, p.178-185, 1990.

RODRIGUES, B.N.; ALMEIDA, F.S. Guia de herbicidas. 4.ed. Londrina: B.N. Rodrigues, 1998. 648p.

SILVA, V.G. Estratégias de manejo de populações resistentes: manejo da planta daninha amendoim-bravo (Euphorbia heterophylla-R/EPHHLR) resistente aos herbicidas inibidores da enzima ALS. In: CURSO DE MANEJO DA RESISTÊNCIA DE PLANTAS DANINHAS AOS HERBICIDAS, 2., Ponta Grossa, 1999. Anais. Ponta Grossa: AECG, 1999. p.141-148.

VARGAS, L.; SILVA, A.A.; BORÉM, A.; REZENDE, S.T.; FERREIRA, F.A; SEDIYAMA, T. Resistência de plantas daninhas a herbicidas. Viçosa: Jard Produções Gráficas, 1999a. 131p.

VARGAS, L.; SILVA, A.A.; BORÉM, A.; OLIVEIRA, S.P. Identificação e manejo de plantas daninhas resistentes a herbicidas. Viçosa: UFV, 1999b. 39p.

VIDAL, R.A. Herbicidas: mecanismos de ação e resistência de plantas. Porto Alegre: Ribas Vidal, 1997. 165p.

VIDAL, R.A.; MEROTTO JR, A. Resistência de amendoim-bravo aos herbicidas inibidores da enzima acetolactato sintase. Planta Daninha, v.17, p.367-373, 1999

WARWICK, S.I. Herbicide resistance in weed plants: physiology and population biology. Annual Review in Ecology and Systematic, v.22, p.95-144, 1991.

Received May 13, 2004

Accepted August 22, 2005 